\title{
Wykorzystanie wahadła odwróconego do modelowania równowagi człowieka
}

\author{
Andrzej Kot (D), Agata Nawrocka (i)
}

AGH Akademia Górniczo-Hutnicza, Wydział Inżynierii Mechanicznej i Robotyki, Kraków

\begin{abstract}
Streszczenie: $\mathrm{Z}$ biomechanicznego punktu widzenia utrzymanie równowagi przez człowieka jest umiejętnością utrzymywania pionowej pozycji wyprostowanej przy zachowaniu minimalnego kołysania całego ciała. Kołysanie to może być zdefiniowane jako ruch środka ciężkości w płaszczyźnie poziomej, występujący nawet w momencie, gdy stoimy nieruchomo. Kołysanie ciała może występować we wszystkich płaszczyznach ruchu, co sprawia, że opis całego modelu staje się bardziej skomplikowany. W badaniach istnieją mocne dowody na to, że deficyty równowagi postawy są związane z kontrolą stabilności przyśrodkowo-bocznej i zwiększonym ryzykiem upadku. Aby zachować równowagę, osoba stojąca musi być w stanie utrzymać środek nacisku w podstawie podparcia, co skutkuje niewielkim kołysaniem przyśrodkowo-bocznym lub przednio-tylnym. Obserwacja trajektorii rzutu środka ciężkości na podłoże, w postaci badania posturograficznego, jest jedna z podstawowych metod oceny stabilności układu równowagi. Od strony biomechanicznej układ równowagi może zostać zamodelowany w postaci wahadła odwróconego o różnym stopniu skomplikowania modelu. Autorzy przedstawili w artykule propozycję podejścia do modelowania układu równowagi w postaci pojedynczego wahadła odwróconego.
\end{abstract}

Słowa kluczowe: modelowanie, równowaga, wahadło odwrócone

\section{THE USE OF AN INVERTED PENDULUM TO MODEL HUMAN BALANCE}

\begin{abstract}
From a biomechanical point of view, human balance is the ability to maintain an upright position with minimal swaying throughout the body. This swing can be defined as the horizontal movement of the center of gravity, even when we are standing still. Rocking of the body can occur in all planes of movement, which makes the description of the overall model more complicated. There is strong evidence in studies that postural imbalances are associated with the control of mediolateral stability and an increased risk of falling. In order to maintain balance, a standing person must be able to maintain a center of pressure in the base of the support, resulting in slight medio-lateral or anterior-posterior swaying. One of the basic methods of assessing the stability of the equilibrium system is the observation of the trajectory of the projection of the center of gravity onto the ground in the form of a posturographic examination. From the biomechanical point of view, the equilibrium system can be modeled in the form of an inverted pendulum with varying degrees of model complexity. The authors of the article presented a proposal of an approach to modeling the equilibrium system in the form of a single inverted pendulum.
\end{abstract}

Keywords: modelling, balance, inverted pendulum

https://doi.org/10.7494/978-83-66727-47-2_6 


\section{Wprowadzenie}

Kontrola pozycji pionowej odbywa się przez nieznaczne przemieszczanie się ciała w płaszczyźnie przednio-tylnej i bocznej, często z przejściem przez punkt równowagi. Dążenie do uzyskania równowagi ciała w pionie nazywa się stabilnością (Winter 1995). Te wychylenia identyfikuje się ze zmianą położenia ogólnego środka ciężkości, a przebiegają one głównie w dwóch obszarach. Pierwszym z tych obszarów jest obszar marginesu stabilności. Ciało wychyla się wtedy w niekontrolowany sposób w promieniu 5 milimetrów. Są to na tyle małe przemieszczenia, że dzieją się poza świadomością człowieka i nie wpływają negatywnie na stabilność. Następnym obszarem jest tak zwany margines bezpieczeństwa. Jeśli zostanie on przekroczony, to odzyskanie równowagi staje się niemożliwe. W obrębie tego obszaru możliwa jest korekcja równowagi za pomocą mechanizmu ruchowego człowieka (Błaszczyk 2004).

\section{Kontrola pozycji pionowej ciała człowieka}

Do kontroli równowagi pionowej pozycji ciała człowiek, w drodze ewolucji, wykształcił różne specyficzne strategie. Pierwsza z nich (rys. 1a), nazywana strategią stawu skokowego, jest stosowana przy małym zaburzeniu pionowej pozycji ciała. Pracują wtedy stawy skokowe, starając się zmienić kąt wychylenia ciała tak, aby powrócić do stanu równowagi. Następna strategia (rys. 1b) wykorzystuje do stabilizacji pozycji mięśnie ud i tułowia, a w późniejszej fazie także mięśnie kończyn dolnych. Towarzyszy ona kontroli postawy osób stojących na wąskim podłożu. Strategia ta nosi nazwę strategii stawu biodrowego. Ostatnią ze strategii (rys. 1c) jest zrobienie kroku. Stosowana jest ona wtedy, kiedy przekroczony zostanie margines bezpieczeństwa i nie da się już odzyskać równowagi. Człowiek wykonuje wtedy krok, aby zapobiec upadkowi. Przedstawione wyżej strategie stanowią specyficzną interakcję pomiędzy systemami sensorycznymi a systemami ruchowymi człowieka (Horak i Nashner 1986).

Ciało człowieka można przyrównać do modelu wahadła odwróconego, a kontrola stabilności odbywa się na dwa różne sposoby. Pierwszy z nich polega na zmianie kąta nachylenia ciała względem płaszczyzny podparcia. Odbywa się to przy zaangażowaniu stawów skokowych człowieka. Informacja o odchyleniu ciała od pionu dociera do mózgu za pośrednictwem receptorów czucia głębokiego ulokowanych na wyżej wymienionych stawach. Sygnały są generowane w wyniku zmiany napięcia i długości mięśni, zmiany kątów w stawach oraz rozkładu sił nacisku na powierzchnie stóp. Na ich podstawie mózg człowieka potrafi się zorientować, jak bardzo ciało wychyla się od pionu (Błaszczyk 1993). 

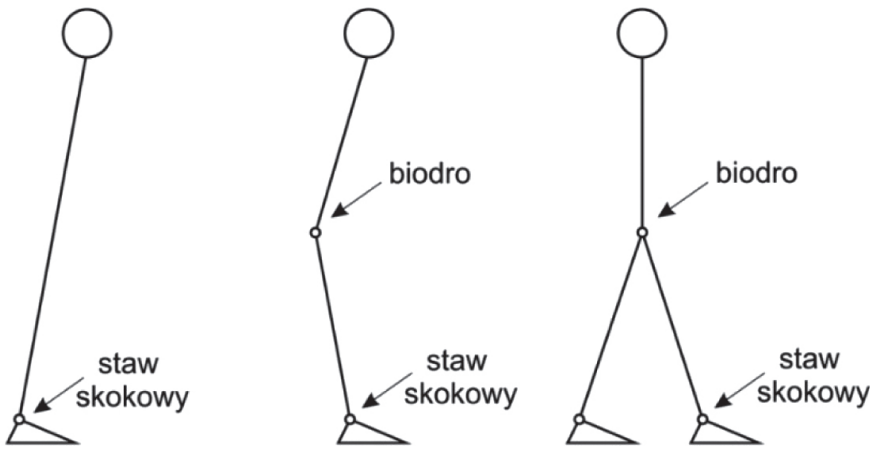

Rys. 1. Strategie utrzymania równowagi

W dalszej części artykułu analizie poddana zostanie strategia stawu skokowego, czyli przypadek potraktowania organizmu człowieka jako wahadła odwróconego.

Najprostszym wariantem wahadła odwróconego jest wahadło odwrócone proste, którego schemat poglądowy ukazany został na rysunku 2. Składa się ono ze sztywnego elementu 1 wykonującego ruch obrotowy względem przegubu 2 oraz ruchomego w osi poziomej wózka 3, którego zmiana położenia pozwala na sterowanie kątem wychylenia wahadła, a w konsekwencji stabilizację wahadła w górnym niestabilnym położeniu (Kot 2013, Kot i Nawrocka 2016). Do opisu matematycznego wykorzystane zostały poniższe oznaczenia:

$M$ - masa wózka,

$m$ - masa wahadła,

$I$ - moment bezwładności wahadła,

$2 l$ - długość wahadła,

$x$ - przemieszczenie wózka,

$\alpha$ - wychylenie kątowe wahadła,

$F$ - siła sterująca,

$g$ - siła ciężkości.

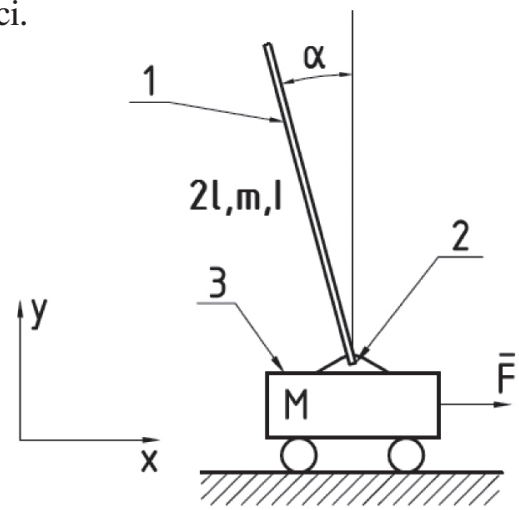

Rys. 2. Schemat wahadła odwróconego prostego 
Dynamiczne równania ruchu wahadła przyjmują następującą postać (Liu 2017):

$$
\left\{\begin{array}{c}
(M+m) \ddot{x}-m l \ddot{\alpha} \cdot \cos \alpha+m l \dot{\alpha}^{2} \cdot \sin \alpha=F \\
\left(I+m l^{2}\right) \ddot{\alpha}-m l \ddot{x} \cdot \cos \alpha=m g l \cdot \sin \alpha
\end{array}\right.
$$

W przypadku gdy wózek jest unieruchomiony, opis matematyczny sprowadza się do opisu wahadła fizycznego.

\section{Modelowanie matematyczne równowagi człowieka}

W odniesieniu do stosowanych przez człowieka, przedstawionych powyżej, strategii utrzymania równowagi (rys. 1) można rozważyć dwa przypadki. W pierwszym z nich w przypadku strategii stawu skokowego człowiek traktowany jest jako pojedyncze wahadło odwrócone. Do modelowania strategii stawu biodrowego wykorzystywany jest natomiast model podwójnego wahadła odwróconego. Rozwinięciem drugiego z przypadków jest potraktowanie drugiego stopnia wahadła jako układu ciągłego (rys. 3).
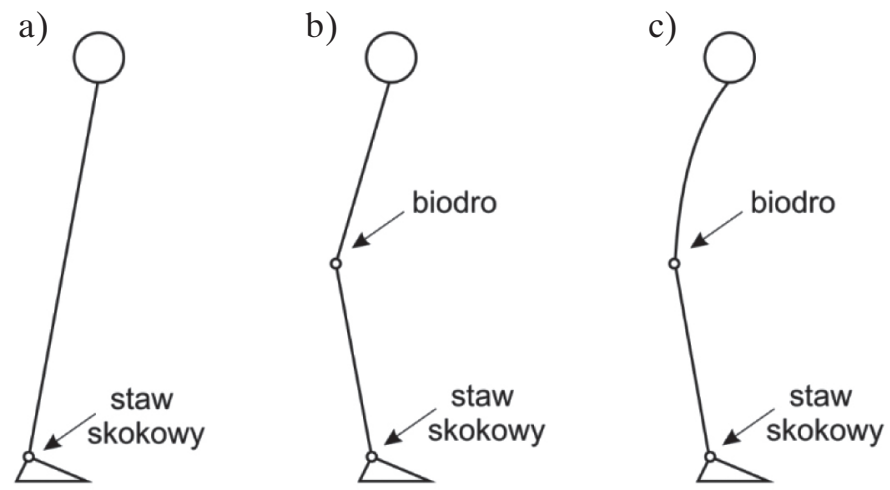

Rys. 3. Strategie zachowania równowagi z rozwinięciem modelu strategii biodrowej:

a) strategia stawu skokowego; b) strategia stawu biodrowego; c) „rozszerzona” strategia stawu biodrowego

Następuje zatem zastąpienie modelu o parametrach skupionych modelem o parametrach rozproszonych (Kot i in. 2018).

W artykule pozycja stojąca człowieka modelowana jest w postaci ruchu wahadła odwróconego przedstawionego na rysunku 4:

$$
\ddot{I}=T_{g}-T
$$


gdzie:

$I$ - moment bezwładności ciała człowieka względem stawu skokowego,

$\theta$ - kąt wychylenia,

$T_{g}$ - grawitacyjny moment przewracający,

$T_{g}=m g h \theta$

$m$ - masa ciała,

$g$ - przyspieszenie grawitacyjne,

$h$ - odległość pomiędzy stawem skokowym a środkiem ciężkości ciała,

$T$ - moment w stawie skokowym,

$T=K \theta+B \dot{\theta}$

$K$ - wewnętrzny współczynnik sprężystości,

$B$ - wewnętrzny współczynnik tłumienia wiskotycznego.

Po podstawieniu zależności (3) i (4) do równania (2) otrzymujemy:

$$
\ddot{I} \ddot{\theta}=m g h \theta-(K \theta+B \dot{\theta})
$$

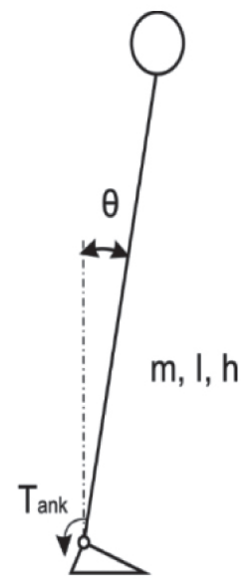

Rys. 4. Model człowieka przedstawionego jako wahadło odwrócone

Przedstawione powyżej równanie powinno dodatkowo uwzględniać opóźnienie związane z przekazywaniem sygnałów nerwowych między mózgiem a mięśniami kontrolującymi staw skokowy. Autorzy założyli jednak, że na obecnym etapie badań nad modelami zachowania równowagi człowieka efekt ten jest pomijalnie mały. Należy 
równocześnie zauważyć, że moment oporowy w stawach skokowych wytwarzany przez układ mięśniowy człowieka będzie się zmieniał wraz ze zwiększającym się wychyleniem. Wspomniany moment ma na celu utrzymanie ciała w pozycji równowagi. W przedstawionych rozważaniach autorzy zakładają, że jego wartość jest stała.

Sprężystość wewnętrzna to odporność na rozciąganie, gdy staw skokowy pozostaje w ruchu. Staje się większa, gdy wielkość zaburzeń pomiarowych jest zmniejszona. W związku z tym aby w pełni ją opisać, konieczne jest wprowadzenie parametrów uwzględniających jej zmienność, takich jak: wiek, sprawność fizyczna lub przebyte urazy.

Sprężystość wewnętrzna odnosi się do naturalnej sprężystej odporności stawu skokowego na jego rotację, przy założeniu niezmiennego poziomu aktywności mięśni. Jest to pasywna właściwość mechaniczna mięśni i ścięgien działających na staw skokowy. Pasywność nie oznacza, że mięśnie są rozluźnione, ale że poziom aktywności nie jest zmieniany przez układ nerwowy. Odwrotnie, aktywnym mechanizmem jest zmiana aktywności mięśni łydek przez układ nerwowy.

Charakterystyki czasowe i częstotliwościowe modelu człowieka w postaci wahadła odwróconego przedstawione na rysunkach 5-8 wykonano dla parametrów przyjętych w literaturze (Asai et al. 2009, Vlutters et al. 2015, Sakanaka et.al. 2021) przy założeniu wagi osoby badanej $75 \mathrm{~kg}$.

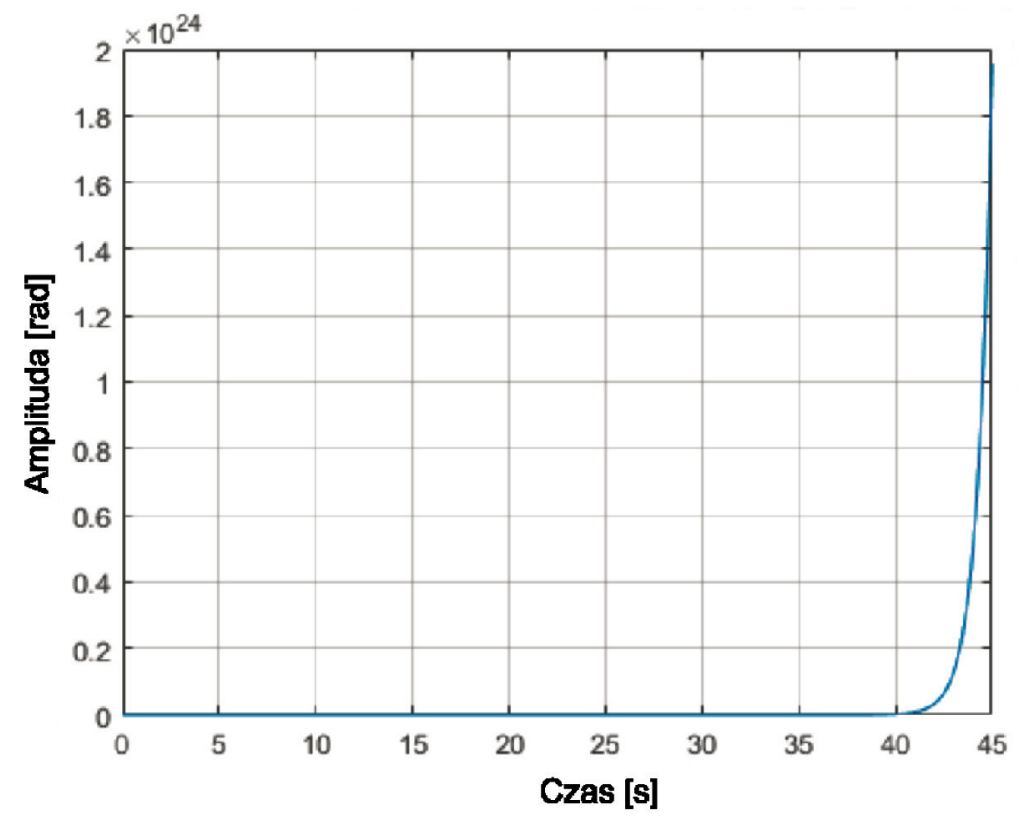

Rys. 5. Odpowiedź skokowa modelowanego wahadła odwróconego dla przypadku mięśni osłabionych 


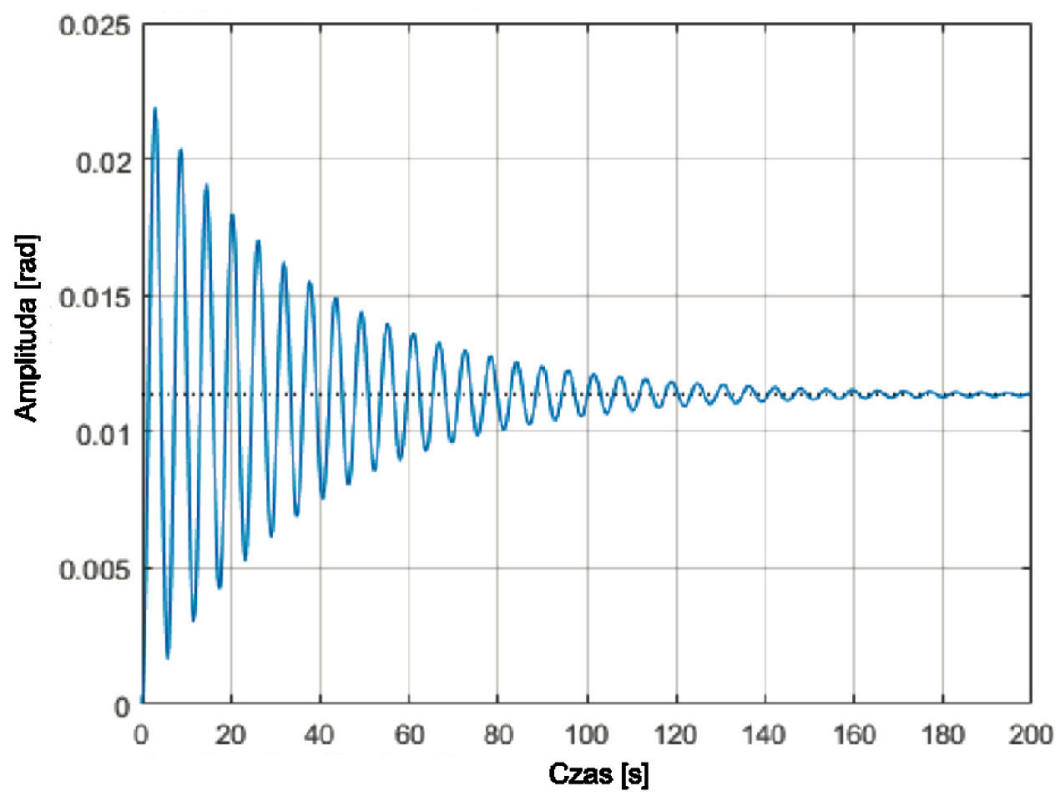

Rys. 6. Odpowiedź skokowa modelowanego wahadła odwróconego dla przypadku mięśni osoby aktywnej

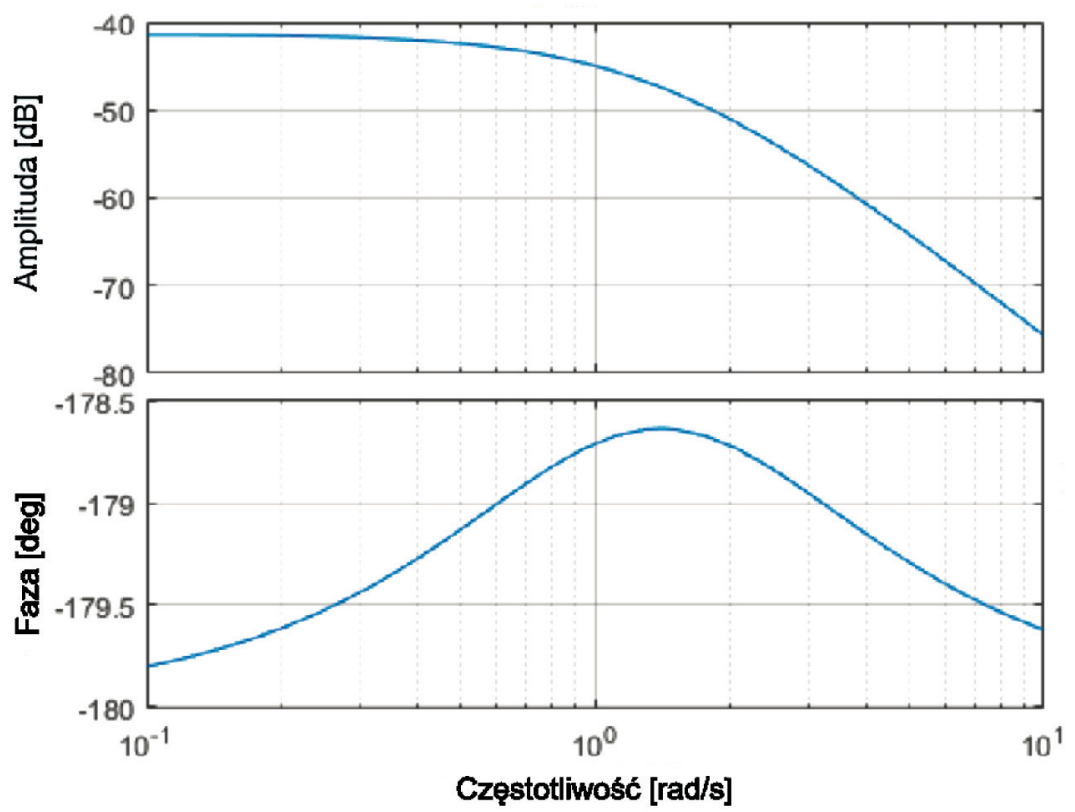

Rys. 7. Charakterystyki częstotliwościowe modelowanego wahadła odwróconego dla przypadku mięśni osłabionych 


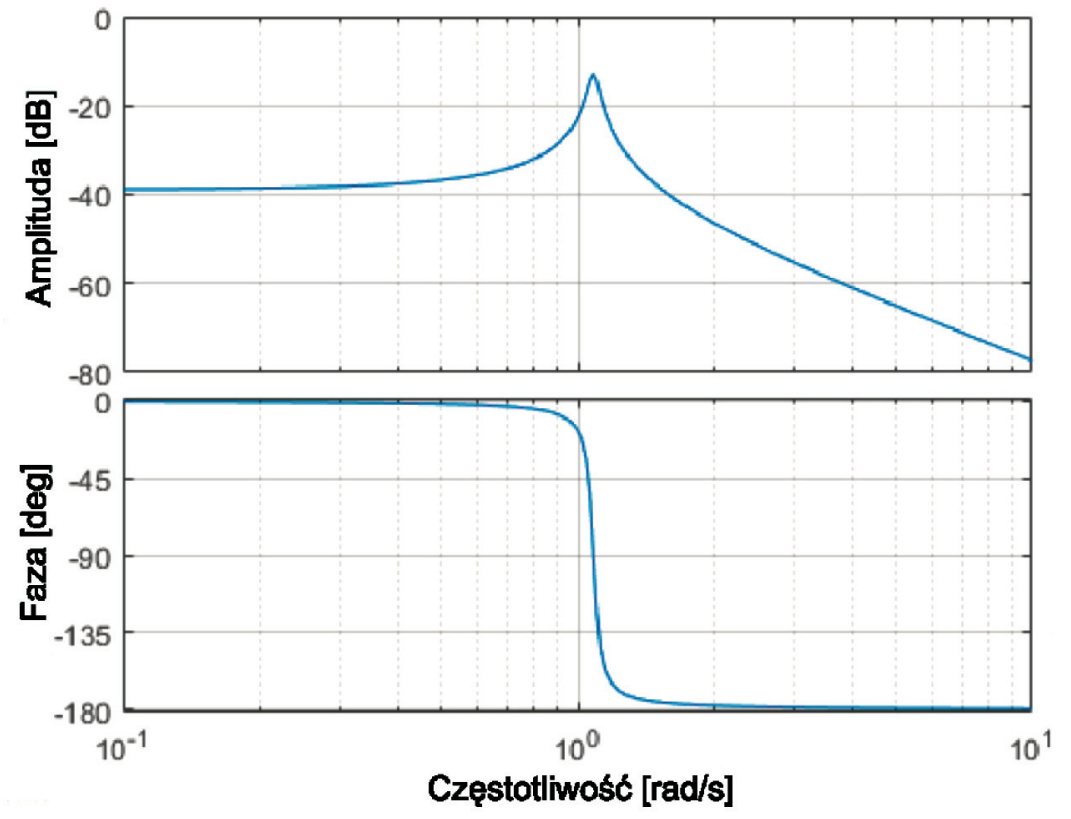

Rys. 8. Charakterystyki częstotliwościowe modelowanego wahadła odwróconego dla przypadku mięśni osoby aktywnej

Ogólnie rzecz biorąc, można stwierdzić, że istnieją wewnętrzne czynniki nerwowomięśniowe, które ograniczają odpowiedź częstotliwościową wahadła odwróconego odpowiadającego ciału człowieka traktowanemu jak bryła sztywna. Zatem coraz trudniej jest dokonać odpowiednio modulowanych regulacji odchylenia pozycji pionowej poza obserwowaną częstotliwość. Ze względu na to, że zadanie utrzymania równowagi w przypadku zaistnienia bodźca o większej prędkości wymaga wyższej odpowiedzi częstotliwościowej w miarę zmniejszania się bezwładności, osoba może utracić kontrolę nad równowagą, zamiast zwiększać częstotliwość regulacji swojego odchylenia przez szybszą reakcję. Szerokość pasma częstotliwościowego można ilościowo oszacować na około $1 \mathrm{~Hz}$.

Prędkość odchylenia i widmo prędkości wahadła odwróconego są powiązane równaniem zdefiniowanym przez Lorama i in. (2005). Jeżeli w odpowiedni sposób zapewnimy kontrolę wychylenia wahadła, przy niskim i ograniczonym zakresie częstotliwości $(\sim 1 \mathrm{~Hz})$, to ze względów biomechanicznych, odzwierciedlających bezwładność, sprężystość i tłumienie realizowane przez antagonistyczne mięśnie, ruch odwróconego wahadła będzie ograniczony do niższego zakresu częstotliwości, w praktyce około $0,5 \mathrm{~Hz}$. Niska częstotliwość może być konsekwencją ograniczenia zakresu częstotliwości wynikającego z charakterystyki organizmu człowieka. Można zatem stwierdzić, że na kształt charakterystyk wpływ może mieć spektrum poprawek, które będą wynikały ze zmian 
momentów bezwładności oraz współczynników sprężystości i tłumienia. Zmiany takie będą naturalne w przypadku pojawienia się urazów czy osłabienia mięśni, a także będą się nasilać z upływem wieku człowieka.

\section{Podsumowanie}

W artykule podjęto próbę opisania układu równowagi człowieka za pomocą modelu wahadła odwróconego. Problematyka zawarta w opracowaniu jest ważna ze względu na coraz częstsze występowanie schorzeń zaburzających układ równowagi człowieka. Model wahadła odwróconego jest najprostszym rozwiązaniem tego problemu. Rozwinięciem tematu, nad którym autorzy pracują, jest opis pozycji stojącej za pomocą modelu podwójnego wahadła odwróconego. Model ten opracowywany jest z wykorzystaniem zasad obowiązujących zarówno dla układów dyskretnych, jak i ciągłych.

Taka różnorodność pozwoli na dokładniejsze odzwierciedlenie procesu utrzymania równowagi, a tym samym - lepsze dopasowanie do naturalnych ruchów człowieka. Istotną kwestią, co pokazały wyniki przeprowadzonej analizy numerycznej, jest zmienność parametrów opisujących własności mechaniczne mięśni człowieka. Na zmienność tę wpływ mogą mieć procesy związane ze starzeniem się organizmu, jak również urazy, do których dojść może w trakcie normalnego codziennego funkcjonowania.

Autorzy widzą w przyszłości możliwość rozwijania przedstawionego modelu matematycznego przy uwzględnieniu zjawisk i zachowań zachodzących w trakcie procesu utrzymania równowagi.

\section{Literatura}

Asai Y., Tasaka Y., Nomura K., Nomura T., Casadio M., Morasso P., 2009, Correction: A Model of Postural Control in Quiet Standing: Robust Compensation of Delay-Induced Instability Using Intermittent Activation of Feedback Control, PLoS ONE, vol. 4(7). https://doi.org/10.1371/annotation/96e08e7f-22f0-445d-8fb3-fe7b071d0a3a.

Błaszczyk J., 1993, Kontrola stabilności postawy ciała, Kosmos, vol. 49, s. 473-486.

Błaszczyk J., 2004, Biomechanika kliniczna: podręcznik dla studentów medycyny i fizjoterapii, Wydawnictwo Lekarskie PZWL, Warszawa.

Horak F.B., Nashner L.M., 1986, Central programming of postural movements: Adaptation to altered support-surface configurations, Journal of Neurophysiology, vol. 55, no. 6, s. 1369-1381. https://doi.org/10.1152/jn.1986.55.6.1369.

Kot A., 2013, Bi-axial inverted pendulum modelling, [w:] 2013 Proceedings of the 14th International Carpathian Control Conference (ICCC), s. 171-174. https://doi.org/ 10.1109/CarpathianCC.2013.6560532. 
Kot A., Nawrocka A., 2016, Balance maintaining by human, Solid State Phenomena, vol. 248, s. 155-160. https://doi.org/10.4028/www.scientific.net/SSP.248.155.

Kot A., Nawrocka A., Sioma A., 2018, Testing of a human sway at balance platform, [w:] 2018 Proceedings of the 19th International Carpathian Control Conference (ICCC), s. 118-121. https://doi.org/10.1109/CarpathianCC.2018.8399613.

Liu J., 2017, Sliding Mode Control Using MATLAB, Elsevier Academic Press.

Loram I.D., Maganaris C.N., Lakie M., 2005, Active, non-spring-like muscle movements in human postural sway: How might paradoxical changes in muscle length be produced?, Journal of Physiology, vol. 564(1), s. 281-293. https://doi.org/10.1113/ jphysiol.2004.073437.

Sakanaka T.E., Lakie M., Reynolds R.F., 2021, Individual differences in intrinsic ankle stiffness and their relationship to body sway and ankle torque, PLoS ONE, vol. 16(1), e0244993. https://doi.org/10.1371/journal.pone.0244993.

Vlutters M., Boonstra T.A., Schouten A.C., van der Kooij H., 2015, Direct measurement of the intrinsic ankle stiffness during standing, Journal of Biomechanics, vol. 48(7), s. 1258-1263. https://doi.org/10.1016/j.jbiomech.2015.03.004.

Winter D.A., 1995, Human balance and posture control during standing and walking, Gait \& Posture, vol. 3(4), s. 193-214. https://doi.org/10.1016/0966-6362(96)82849-9. 